\title{
CONSIDERATIONS REGARDING ENVIRONMENT PROTECTION IN HUMAN SETTLEMENTS
}

\author{
G. Paraschiv
}

\section{Gavril Paraschiv}

Faculty of Law and Public Administration, Craiova, "Spiru Haret" University, Romania

*Correspondence: Gavril Paraschiv, 30 General Magheru St., Râmnicu Vâlcea, Vâlcea, Romania E-mail: gavril.paraschiv@yahoo.com

\begin{abstract}
Across time, the concept regarding the quality of life determined public authorities to take into consideration the improvement of urban and rural space, the zoning, the servitudes, imposed on individuals and even authorities, being gradually accepted in the name of the necessity for a collective welfare, including from the point of view of the natural environment. Inveterated legal regulation, which concern the protection of ancient monuments in order to save common cultural heritage, were gradually added to the ecological requests, which tend to acquire preponderance compared to the traditional domains of urbanism and territory planning.

Human settlements represent the traditional environment of human communities, thus the approach to their sustainable and ecological development must be primarily acquired.

Resolving ecological issued in human settlements greatly depends of the dimensions of localities, of their relations with the free territory, of the nature and manner of exploiting this territory, of the existent resources, of the network communication means, of the industrial objectives, etc. Thus many parameters must be taken into consideration when studying the habitats of these settlements compared to those used in natural ecosystems.
\end{abstract} regulations

Key-words: the quality and protection of environment, sustainable development,

\section{Introduction}

The right to a healthy environment that is ecologically balanced constitutes a natural right, of the same importance as the right to property, and in close connection with the latter.

Being one of the fundamental human rights, the right to a healthy environment that is ecologically balanced is characterised by a special dynamics regarding its acknowledgement and legal guarantee.

Initially being internationally proclaimed by the Declaration in Stockholm, from the year 1972, this right is constitutionally and legally consecrated on state level. It stands for human liability for environment, especially conjugated with its correlative right to a healthy environment that is ecologically balanced, in case the ecological issues are mainly generated by the sociohuman impact upon the surrounding nature.

\section{General conditions regarding environment factor protection in human settlements}

The general principles, action framework and objectives of human settlements protection were established at the Conference in Vancouver from 1976. In the Declaration adopted it was stated that in the conditions in which the majority of the population, especially underdeveloped countries, is living in poor settlements conditions, if concrete measures are not taken at a national and international level, the situation will degenerate due to: inequitable economic growth, unequal social, economic and ecological conditions, increasing food and housing necessities and other 
indispensible elements., along with the increase in population and uncontrolled urbanization which will lead to overpopulation in cities and dispersions in the rural environment.

The measures which were taken from adopting this document and to the present proved to be extremely scarce and almost inefficient compared to the existent realities, thus it would be necessary that governments and the international communities to act in favor of adopting efficient strategies and policies concerning human settlements, taking into consideration the necessities of defavored groups, especially children, women and cripples - in order to ensure medical care, services, education, food and workplaces.

Sustainable development of human settlements imposes the guarantee of a healthy environment which is functionally and culturally coherent, at the level of rural and urban localities, in the conditions of preserving a balance regarding the resource resorts of the natural capital.

Environment protection in human settlements focuses on environment factors: air, water, soil, subsoil, noise, radiations, etc. and is achieved by pollution control methods by means of technical methods and procedures such as: placing polluting industries at a distance from localities; reducing pollution resulted from means of transport, using technological methods that produce as less contaminants as possible; neutralization of unrecoverable waste; reduction of noise pollution; developing dangerous activities for humans and the environment in conditions of safety, etc.

The effects of pollution affect the quality of air - the basic component of the environment, which by its physical, chemical and thermical properties sustains the planet life - as well as a series of atmospherical processes and phenomenon, which may produce meteorological and climatological effects especially difficult to control, such as: the greenhouse effect, acid rain, ozone depletion.

The quality of air is statistically relevant for many indicators which represent the pollution phenomenon under the form of polluting residual substances spreading into the air, resulted from economical activities or other sources, which requires the monitoring of air quality in the areas with strong polluting emissions.

Noise pollution is, also, an environment and health issue, especially in crowded urban centers where noise levels exceeding the standards in the domain are recorded, as a result of intense automobile traffic.

For human ecology, one of the most urgent issues is ensuring drinking water, which strongly requires the limitation of excessive consumption of water and pollution, thus restoring the consumed water which now possesses more natural properties to the environment.

Likewise, it is necessary to ensure the protection of the quality of water, which also implies distinguishing the pollution sources and the composition of wastewater, in order to correctly apply the treatment and evacuation procedures in the local sewerage networks.

The soil also represents an important factor for human settlements, as its degradation may be the result of erosion produced by water and wind, but especially of inadequate agriculture practice, irrational chemicalization, and poorly applied irrigations as well as the absence of the later.

In order to synchronize sustainable development actions within the member states of the European Union, in the year 2001 the Strategy for Sustainable Development of the European Union was established, which provide the following main objectives: redimensioning and reshaping economic and social structure, transforming it into a sustainable system; determining sectors and directions with a competitive potential as priorities of sustainable development; ensuring the health state of the population; ceasing the deterioration process of the natural capital and initiation of its restoration; improving a coherent legal system, compatible with the developed countries in the European Union; forming human resources at the level of scientific, technological and informational requirements on an international scale, from all economic and social sectors; permanent monitoring and evaluation of the economic, social and environment protection performances. 


\section{Environment protection measures in Romania}

Being a responsibility of the public administration authorities, as well as natural and legal persons, human settlement protection is regulated by the Emergency Ordonance no. 195/2005 ${ }^{1}$, which stipulates the impositions of obligations on such liable actors and establishing some ecological requirements regarding the urbanism and territorial management plans

Art. 70, from this normative act stipulates, for ensuring a healthy environment, that local authorities, natural and legal persons are compelled:

- To improve locality microclimate, by managing and maintaining springs and pockets of water from within and adjacent areas, to embellish and protect the landscape, to maintain street cleaning;

- To anticipate, in the establishing of urbanism and territorial management plans, the improvement of natural landscape background, landscape and ecological restoration of deteriorated areas, sanitary protection of drinking water intakes and safety measures against floods;

- To comply with dispositions from the urbanism and territorial management plans regarding the localization of industrial objectives, sewage networks, wastewater treatment, municipal, road and industrial landfills as well as other objectives and activities, without damaging the environment, recreation, treatment and relaxation spaces, health state and comfort of the population;

- To inform the public upon the perils generated by the functioning or existence of objectives involving risks for the population health and for the environment;

- To comply with the regime of special protection for spa localities, tourist interest and recreational areas, historical monuments, protected areas and monuments of nature;

- To adopt adequate architectural elements, to optimize the density of dwellings, while maintaining, sustaining and developing green areas, parks, of trees alignments and road protection belts, of landscape management embodying an ecological, aesthetical and recreational function, in conformity with urbanism and territorial management plans;

- To regulate, including by permanent or temporal prohibition, the access of certain types of vehicles or development of activities which generate discomfort to the population in certain locality areas, predominantly in the areas destined to dwellings, treatment, rest, recreation and enjoyment;

- Not to degrade the natural or landscaped environment, by uncontrolled deposit of any types of waste;

- To adopt compulsory measures, for natural and legal persons, regarding the maintenance and embellishment of buildings, courts and their fencing, of the green spaces from the courts and buildings, of trees and decorative shrubs;

- To initiate, at a local level, sewage management, maintenance and development programs.

For adopting urbanism plans and programs in the domains specifically mentioned by law, the environment evaluation is necessary, before commencing the compulsory regulation procedure of activities that produce negative effects upon the environment, proceedings which focuses on the integration of environment protection obligations and requirements in adopting certain plans and programs, taking into consideration the environment report and the results of these consultations in the decisional process and ensuring informing upon the decision taken.

The environment evaluation procedure, the structure of environment report and conditions for issuing the environmental permit for plans and programs, are established by a government decision, at the proposal of central public authorities for environment protection - approvement of plans and programs, at every hierarchical level being conditioned by the existence of an environment permit for the above-mentioned plan or program.

Moreover, the urbanism plans and programs are also submitted to environment evaluation, which, due to the possible effects, affects the Special Bird Protection Areas or the special areas

\footnotetext{
${ }^{1}$ The Emergency Ordonance no. 195/2005 regarding environment protection, published in the Official Gazette no. 1196 from the $30^{\text {th }}$ of December 2005.
} 
of preservation regulated by the Government Emergency Ordonance no 236/2000 regarding the regime of protected natural areas, preserving natural habitats, flora and savage fauna, approved with amendments and additions by the Law no. 462/2001.

After performing the environment evaluation and the environment report for certain plans and programs, the competent authorities issue an environment permit, which has the same availability as the program or plan for which it was issued.

An important domain for ensuring a healthy environment within the human settlements is maintaining, sustaining and developing green spaces ${ }^{2}$ whose administration is regulated by the Law no. 24/2007.

Regardless of the nature of the property (public or private) these spaces are submitted to a common protection and preservation regime, based on acknowledging the right of every natural person to a healthy environment, free access to recreation in the green spaces which represent public property etc., in the conditions of complying with legal dispositions in force.

In view of complying with rules and protection and preservation measures, the law stipulates a series of obligations for the natural and legal persons, and for the control and coordination of the activities developed, an inventory conducted by the National Register of green spaces and green local registers was established.

In conformity with the sixth Program of action for the environment performed by the European union, adopted by the decision of the European Parliament and Council no. 1600/2002/EC, our country initiated the National Program of air quality improvement by establishing green spaces in localities ${ }^{3}$, document by which the increase in the surfaces of green spaces from localities is targeted, in order to reach the standard European sizes, by establishing green spaces in localities and building new parks, squares, alignments planted or the rehabilitation of the ones existent.

\section{Conclusions}

By studying the vast problem of environment protection in human settlements, we can detach a multitude of aspects related to this domain, as well as measures imposed for ensuring an adequate environment, which must contribute to the improvement of the quality of life and to the health of the population.

Thus, the health and people's lives, as well as the quality of the environment, may be affected not only by emissions resulted from industrial activities, but also the quality of products and services offered.

In view of ensuring the protection of people health and life, as well as environment, domestic animals and property protection, competent authorities elaborate technical regulations, by respecting international and community principles and regarding the free circulation of goods in the domestic and international commerce.

For new non-food or reconditioned products and for the services which threaten life, health, work security and environment protection, non-regulated by specific normative acts, referring to the marketing conditions ${ }^{4}$ of products and respectively, services, the dispositions of the Government Decision no. 1022/2002 is applied, in conformity to which the service supplier or his authorized representatives guarantee that these products are not threatening to life, health, work security and environment protection, in the conditions in which they are installed, used,

\footnotetext{
${ }^{2}$ Art. 1 from Law no. 24/2007 considers that these activities represent a public interest objective, as to ensure the quality of environment factors and the population's health state.

${ }^{3}$ The Emergency Government Agency no. 59 from 20 June 2007 regarding the establishment of the National improvement program of the quality of the environment by creating green spaces in localities, published in the Official Gazette no. 441 from 29.VI.2007.

${ }^{4}$ In accordance with the Government Decision no. 1022/10.IX.2002 regarding the regime of products and services which endanger health, work security and environment protection, published in the Official Monitor no. 711/30.IX.2002, by "placing on market" the action of making available is understood, either for cost or free of charge, a new non-food item, used or reconditioned or a service, as to distribute, utilise or provide.
} 
maintained or performed, after each case, in conformity with their destination and normative documents defined in conformity with the law.

Invading the market with poor quality products and the alarming increase of cases of sickness, as well as producing other damages, have determined the regulation of product general security $^{5}$, in conformity with community regulations, as well as civil liability for the damages generated by these products, as well as the procedure of repairing them ${ }^{6}$.

By the Law no 150/2004 regarding food and feed safety for animals with the subsequent amendments and additions, a unitary legal framework was established referring to the production, packaging, storage, transportation and marketing of food, the liabilities of food producers and traders and the sanctions applicable in the domain.

In order to supply the consumer with the necessary, sufficient, verifiable and easy to compare information, as to permit them to choose a product that corresponds with the requirements from the point of view of financial needs and possibilities, as well as acknowledging the possible risks to which they may be submitted, the methodological rules ${ }^{7}$ that regulate the manner of labelling the products delivered to the final consumer or restaurants, hospitals, cantines and other economic agents that manufacture and supply food for the population were adopted.

Activities that concern the deliberate introduction in the environment and on the market of genetically modified organisms, as well as using them in conditions of isolation of genetically modified micro-organisms or that were submitted to a special regulation, authorization and administration regime, in conformity with the dispositions of the national and community legislation $^{8}$, and of the international legal acts In which Romania is included.

In the present, the enhancement of preoccupations from the public authorities for environment protection is generally expected, but especially in human settlements, as guides for the implementation of the procedure for risks evaluation is being established, this being in conformity with the European Union policy and the international regulations in the domain.

\section{Bibliography}

M. Duţu, Dreptul mediului, $3^{\text {rd }}$ Edition, “C.H. Beck” Press, Bucharest, 2010;

Marinescu Daniela, Tratat de dreptul mediului, Third edition, reviewed and completed, "Universul Juridic" Press, Bucharest, 2008;

M. Duțu, Tratat de dreptul mediului, $3^{\text {rd }}$ Edition, "C.H. Beck" Press, Bucharest, 2007;

S. Godeanu, M. Godeanu, M. Popescu, Ecodezvoltare sau dezvoltare durabilăa, in Ecologie şi protecția mediului, Coresi Press, 1992.

\footnotetext{
5 Law no. 245/9 June 2004 regarding general product security, published in the Official Gazette no. 565/25.VI.2004. The Law transposes Directive no. 2001/95/CE of the European Parliament and the Council of Europe from the 3rd of December 2001, referring to general product security, published in the Official Gazette of the European Communities L.11 from 15.I.2002.

${ }^{6}$ See Law no. 240/7 June 2004 regarding producers liabilities for damages generated by products with defects, published in the Official Gazette no. 555/22.VI.2004.

7 See Government Decision no 106/7.II.2002 regarding food labeling, published in the Official Gazette no. 147/27.II.2002.

${ }^{8}$ This regime was established by the Goverment Ordonance no. 49/30.I.2000 regarding the regime of obtaining, testing, utilization and marketing of genetically modified organisms by means of modern biotechnological techniques, as well as the products resulted from it, published in the Official Gazette no. 48/31.I.2000, approved with amendments by the Law no. 214/3.V.2002, published in the Official Gazette no.316/14.V.2002.
} 